\author{
S. Pylypaka ${ }^{1}$, M. Klendii ${ }^{2}$, V. Trokhaniak ${ }^{3}$ \\ ${ }^{1}$ National University of Life and Environmental Sciences of Ukraine, Kiev, Ukraine; \\ ${ }^{2}$ Separated Subdivision of National University of Life and Environmental Sciences of Ukraine, Kiev, Ukraine; \\ ${ }^{3}$ Berezhany Agrotechnical Institute, Ukraine \\ (E-mail: trohaniak.v@gmail.com)
}

\title{
Particle motion over a plane, which rotates about a horizontal axis and makes a certain angle with it
}

Differential equations of relative material particle motion over a plane, which rotates about a horizontal axis, have been set up. Plane location relative to a rotation axis is set by a certain angle, which value can range from zero to ninety degrees. If angle value is equal to zero, a plane passes through a rotation axis; if angle value equals to 90 degrees, it is perpendicular to a rotation axis. The equations have been solved using numerical methods. In case of end positions of an angle, analytical solution has been found.

Keywords: soil-tilling disk, rotary motion, differential equations of motion.

\section{Introduction}

Particle motion over a horizontal plane in the form of a rough disk, which rotates about a vertical axis, is considered to be the most investigated one. Such disks with blades attached to them are used in scatters of centrifugal type. Operating elements with a horizontal axis of rotation in the form of a shaft with flat blades attached to it are used for spreading organic fertilizers. They can be also used to mix particles or scatter them in a centrifugal direction. It is interesting from theoretical perspective and it is to the point for the possibility of practical implementation to investigate particle motion over a plane, which rotates about a horizontal axis and makes a certain angle with it.

Compound particle motion over rough surfaces of operating elements of agricultural machinery has been considered in the major works [1-4]. They investigate particle motion over a horizontal disk, which rotates about a vertical axis, both without blades and with blades of the simplest designs. Paper [5] considers particle motion over a flat disk, which rotates about the axis that is inclined to the horizon. Patterns of particle motion over a disk both without blades and with straight blades arranged in radial direction from the axis of rotation have been investigated. The research presented in paper [6] is similar to ours but with the difference that the axis of rotation is not horizontal but a vertical one. This research considers relative particle motion in a wide range of angles of inclination of a plane to a rotation axis, beginning from a horizontal position and finishing with a vertical one. The development of a bladed operating element of a conveyer-mixer has been considered in paper [7]. There is a separate group of scientific papers, which investigate particle motion on a rough surface under the action of weight force $[4,8-15,16,17]$.

\section{Material and method}

Let us locate a plane in the form of a rectangle, which will be rotated, in three-dimensional coordinates $O X Y Z$. Firstly, let it be in agreement with a horizontal plane $O X Y$, here, we set our own coordinate axes: $O u$ axis lies in $O X$ solid axis and $O v$ axis lies in $O Y$ axis (Fig. 1, a).

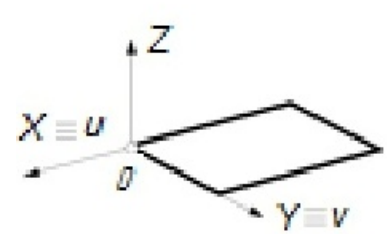

a)

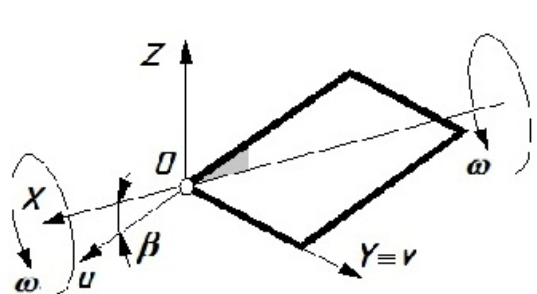

b)

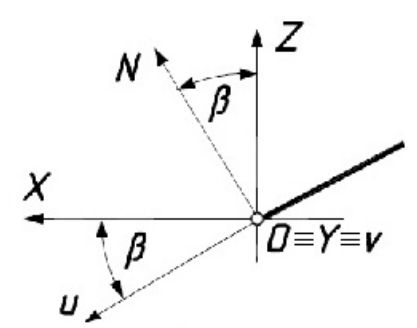

c)

Figure 1. Location of a rectangular section of a plane in three-dimensional coordinates OXYZ 
Let us rotate a plane about $O Y$ axis by a certain angle $\beta$ (Fig. 1, b) and fix it in this position. Figure 1, $c$ shows plane location in three-dimensional coordinates $O X Y Z$, when $O Y$ axis of the latter is projected to a point and the plane itself is projected to a line.

Parametric equations of a plane in projections onto solid axes $O X Y Z$ are written as:

$$
\begin{aligned}
& X=u \cos \beta \\
& Y=v ; \\
& Z=u \sin \beta .
\end{aligned}
$$

Let us rotate a plane about $O Z$ axis with constant angular velocity $\omega$. Then, during time $t$ a moving plane rotates through an angle $\varphi$ relative to a fixed system. The degree of rotation angle $\varphi$ is determined by the familiar formula:

$$
\phi=\omega t \text {. }
$$

Parametric equations of a plane after its turn by the angle $\varphi=\omega t$ about $O X$ axis are written as:

$$
\begin{aligned}
& X=u \cos \beta \\
& Y=v \cos \omega t-u \sin \beta \sin \omega t \\
& Z=v \sin \omega t+u \sin \beta \cos \omega t
\end{aligned}
$$

Figure 2 shows a set of separate plane positions built at equal time intervals. It bends round a cone with axis.
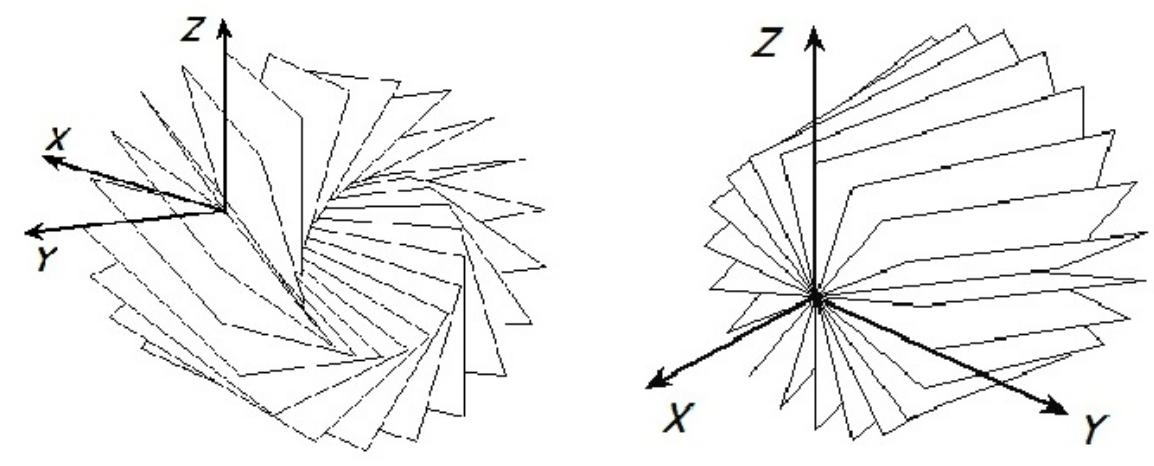

Figure 2. Set of separate plane positions built at its rotation about OX axis

During plane rotation a material particle slides over it having relative motion. Here, its coordinates $u$ and $v$ in a plane will vary with time, that is why, we consider them to be time-varying functions $t: u=u(t), v=v(t)$. Such a relation between independent variables $u$ and $v$ through the third variable $t$ describes a certain line in a plane - a trajectory of relative motion. Provided that $u=u(t)$ and $v=v(t)$, the equations (3) also describe a line in three-dimensional coordinate system - a trajectory of absolute motion of a particle.

Projections of absolute velocity and absolute acceleration of a particle on the axes of a fixed $O X Y Z$ coordinate system are determined by successive differentiation of the equations (3), considering $u$ and $v$ to be unknown functions.

After differentiation of (3) and grouping of terms we get projections of absolute velocity:

$$
\begin{aligned}
& x^{\prime}=u^{\prime} \cos \beta \\
& y^{\prime}=\left(v^{\prime}-u \omega \sin \beta\right) \cos \omega t-\left(u^{\prime} \sin \beta+v \omega\right) \sin \omega t \\
& z^{\prime}=\left(v^{\prime}-u \omega \sin \beta\right) \sin \omega t+\left(u^{\prime} \sin \beta+v \omega\right) \cos \omega t .
\end{aligned}
$$

Here, let us denote coordinates $x, y, z$ not by capital letters as it is in (3) but by lowercase letters, since we moved from the equations with two variables to the equations with one variable $t$. After differentiating the equations (4) and grouping of terms we get projections of absolute acceleration:

$$
\begin{aligned}
& x^{\prime \prime}=u^{\prime \prime} \cos \beta \\
& y^{\prime \prime}=\left(v^{\prime \prime}-v \omega^{2}-2 u^{\prime} \omega \sin \beta\right) \cos \omega t-\left(u^{\prime \prime} \sin \beta+2 v^{\prime} \omega-u \omega^{2} \sin \beta\right) \sin \omega t \\
& z^{\prime \prime}=\left(v^{\prime \prime}-v \omega^{2}-2 u^{\prime} \omega \sin \beta\right) \sin \omega t+\left(u^{\prime \prime} \sin \beta+2 v^{\prime} \omega-u \omega^{2} \sin \beta\right) \cos \omega t
\end{aligned}
$$


Let us establish a motion equation in the form of $m \bar{w}=\bar{F}$, where $m$ - mass of a particle, $\bar{w}$ - vector of absolute acceleration, $\bar{F}$ - resultant vector of the forces exerted upon a particle. Such forces are weight force $m g(g=9,81 \mathrm{~m} / \mathrm{s} 2)$, reaction $N$ of a plane and friction force $f N$ at particle sliding over a plane $f$ - friction coefficient). All the forces must be projected on the axes of a fixed coordinate system.

Weight force is downward-directed, thus, its projections can be written as: $\{0 ; 0 ;-m g\}$.

Plane reaction $N$ is perpendicular to it (Fig. 1, c) and its projections are the following:

$$
\{-N \sin \beta ; 0 ; N \cos \beta\} .
$$

Friction force is directed at a tangent to the trajectory of relative motion opposite to the direction of velocity. Let us find projections of velocity vector of relative motion by differentiating the expressions (1), assuming that $u=u(t)$ and $v=v(t)$ :

$$
\begin{aligned}
& x^{\prime}=u^{\prime} \cos \beta ; \\
& y^{\prime}=v^{\prime} \\
& z^{\prime}=u^{\prime} \sin \beta .
\end{aligned}
$$

Relative velocity value is determined by geometric sum of the components ( 7$)$

$$
V=\sqrt{x^{\prime 2}+y^{\prime 2}+z^{\prime 2}}=\sqrt{u^{\prime 2}+v^{\prime 2}} .
$$

A unit vector, which is at a tangent to the trajectory of relative motion, is determined from dividing the projections (7) by the value of velocity (8). Taking into account that friction force $f N$ is directed opposite to the direction of relative particle motion, its projections can be written as:

$$
\left\{-f N \frac{u^{\prime} \cos \beta}{\sqrt{u^{\prime 2}+v^{\prime 2}}} ; \quad-f N \frac{v^{\prime}}{\sqrt{u^{\prime 2}+v^{\prime 2}}} ; \quad-f N \frac{u^{\prime} \sin \beta}{\sqrt{u^{\prime 2}+v^{\prime 2}}}\right\} .
$$

Weight force (6) does not change its direction during plane rotation. Plane reaction force $N(7)$ and friction force (9) depend on rotation angle $\varphi(2)$ of a plane. Thus, they must be also turned through the angle $\varphi=\omega t$ about axis. Having taken that into consideration, projections of plane reaction force $N$ take the following form:

$$
\left\{\begin{array}{l}
-N \sin \beta ; \\
-N \cos \beta \sin \omega t ; \\
N \cos \beta \cos \omega t
\end{array}\right\} .
$$

Projections of friction force after a turn through the angle $\varphi=\omega t$ can be written as:

$$
\left\{\begin{array}{l}
-f N \frac{u^{\prime} \cos \beta}{\sqrt{u^{\prime 2}+v^{\prime 2}}} ; \\
-f N \frac{v^{\prime} \cos \omega t-u^{\prime} \sin \beta \sin \omega t}{\sqrt{u^{\prime 2}+v^{\prime 2}}} ; \\
-f N \frac{v^{\prime} \sin \omega t+u^{\prime} \sin \beta \cos \omega t}{\sqrt{u^{\prime 2}+v^{\prime 2}}} .
\end{array}\right\}
$$

Let us set up a vector equation $m \bar{w}=\bar{F}$ in projections on the axes of a fixed three-dimensional coordinates, taking into account the applied forces (6), (10) and (11):

$$
\begin{aligned}
& m x^{\prime \prime}=-N\left(\sin \beta+f \frac{u^{\prime} \cos }{\sqrt{u^{\prime 2}+v^{\prime 2}}}\right) ; \\
& m y^{\prime \prime}=-N\left(\begin{array}{l}
\cos \beta \sin \omega t+ \\
+f \frac{v^{\prime} \cos \omega t-u^{\prime} \sin \beta \sin \omega t}{\sqrt{u^{\prime 2}+v^{\prime 2}}}
\end{array}\right) ; \\
& m z^{\prime \prime}=N\left(\begin{array}{l}
\cos \beta \cos \omega t- \\
-f \frac{v^{\prime} \sin \omega t+u^{\prime} \sin \beta \cos \omega t}{\sqrt{u^{\prime 2}+v^{\prime 2}}}
\end{array}\right)-m g .
\end{aligned}
$$


Let us substitute other derivatives (projections of absolute acceleration) from (5) into the equation (12). The obtained set of three equations contains three unknown functions: $N=N(t), u=u(t)$ and $v=v(t)$. Let us solve it for $N, u^{\prime \prime}$ and $v^{\prime \prime}$ :

$$
\begin{aligned}
& \left\{\begin{array}{l}
u^{\prime \prime}=-\sin \beta\left[g \cos \omega t+\omega\left(2 v^{\prime}-u \omega \sin \beta\right)\right]-u^{\prime} f \cos \beta \frac{g \cos \omega t+\omega\left(2 v^{\prime}-u \omega \sin \beta\right)}{\sqrt{u^{\prime 2}+v^{\prime 2}}} \\
v^{\prime \prime}=-g \sin \omega t+\omega\left(v \omega+2 u^{\prime} \sin \beta\right)-v^{\prime} f \cos \beta \frac{g \cos \omega t+\omega\left(2 v^{\prime}-u \omega \sin \beta\right)}{\sqrt{u^{\prime 2}+v^{\prime 2}}} .
\end{array}\right. \\
& N=m \cos \beta\left[g \cos \omega t+\omega\left(2 v^{\prime}-u \omega \sin \beta\right)\right] .
\end{aligned}
$$

The first two equations make a system of nonlinear differential equations of the second order for the functions that describe the trajectory of relative particle motion over a plane.

Let us consider a partial case, when angle $\beta=0$. In such a case a plane passes through axis which is its rotational axis (Fig. 1, a). Here, particle motion is possible in radial direction parallel to $v$ axis at $u=$ const. In this case the system (13) is simplified:

$$
\left\{\begin{array}{l}
u^{\prime \prime}=-u^{\prime} f \frac{g \cos \omega t+2 v^{\prime} \omega}{\sqrt{u^{\prime 2}+v^{\prime 2}}} \\
v^{\prime \prime}=-g \sin \omega t+v \omega^{2}-v^{\prime} f \frac{g \cos \omega t+2 v^{\prime} \omega}{\sqrt{u^{\prime 2}+v^{\prime 2}}} .
\end{array}\right.
$$

At $u=$ const the first equation of the system (14) is changed into an identical equation and we obtain only one linear differential second-order equation:

$$
v^{\prime \prime}=-g \sin \omega t+v \omega^{2}-f\left(g \cos \omega t+2 v^{\prime} \omega\right)
$$

The equation (15) has its analytical solution:

$$
v=e^{-\left(f+\sqrt{1+f^{2}}\right) \omega t}\left(c_{1}+c_{2} e^{2 \sqrt{1+f^{2}} \omega t}\right)+g \frac{2 f \cos \omega t+\left(1-f^{2}\right) \sin \omega t}{2\left(1+f^{2}\right) \omega^{2}} .
$$

For further determination of the values of integration constants ${ }_{1}$ and ${ }_{2}$ let us find the expression of relative velocity by differentiating the equation (16):

$$
\begin{gathered}
V=\frac{d v}{d t}=-e^{-\left(f+\sqrt{1+f^{2}}\right) \omega t} \omega\left[c_{1}\left(f+\sqrt{1+f^{2}}\right)+c_{2}\left(f-\sqrt{1+f^{2}}\right) e^{2 \sqrt{1+f^{2}} \omega t}\right]+ \\
+g \frac{\left(1-f^{2}\right) \cos \omega t-2 f \sin \omega t}{2\left(1+f^{2}\right) \omega}
\end{gathered}
$$

Let a particle be separated from the axis of rotation by the distance $v_{0}$ at the initial time point, when a plane is in a horizontal position (that is to say, at $t=0$ ), and have initial velocity $V_{0}$. Let us substitute $t=0$ into (16) and (17) and equate these expressions to relative initial values of position and velocity and we obtain a set of two equations for unknown constants $c_{1}$ and $c_{2}$ :

$$
\left\{\begin{array}{l}
v_{0}=\frac{f g}{\left(1+f^{2}\right) \omega^{2}}+c_{1}+c_{2} \\
V_{0}=\frac{g\left(1-f^{2}\right)}{2 \omega\left(1+f^{2}\right)}-\omega\left[\sqrt{1+f^{2}}\left(c_{1}-c_{2}\right)+f\left(c_{1}+c_{2}\right)\right] .
\end{array}\right.
$$

Having solved (18) for $c_{1}$ and $c_{2}$, we obtain expressions for the determination of these constants:

$$
\begin{gathered}
c_{1}=\frac{g\left(1+f^{2}-2 f \sqrt{1+f^{2}}\right)-2 \omega\left(1+f^{2}\right)\left[V_{0}+v_{0} \omega\left(f-\sqrt{1+f^{2}}\right)\right]}{4 \omega^{2}\left(1+f^{2}\right)^{3 / 2}} \\
c_{2}=\frac{-g\left(1+f^{2}+2 f \sqrt{1+f^{2}}\right)+2 \omega\left(1+f^{2}\right)\left[V_{0}+v_{0} \omega\left(f+\sqrt{1+f^{2}}\right)\right]}{4 \omega^{2}\left(1+f^{2}\right)^{3 / 2}} .
\end{gathered}
$$




\section{Results}

Figure 3 represents dependency graphs (16) and (17) under set initial conditions $v_{0}=0,2 m$ and $V_{0}=0$ and friction coefficient $f=0,3$. They show that a particle can move in radial direction either away from a rotation axis or towards it. It depends on the value of angular velocity of plane rotation. At $\omega=5 s^{-1}$ - a particle moves towards a rotation axis, here, in the line of about $0,1 \mathrm{~s}$ it practically does not move and only at its turn from a horizontal position to the angle $\varphi$, which is close to a friction angle, it begins to move.
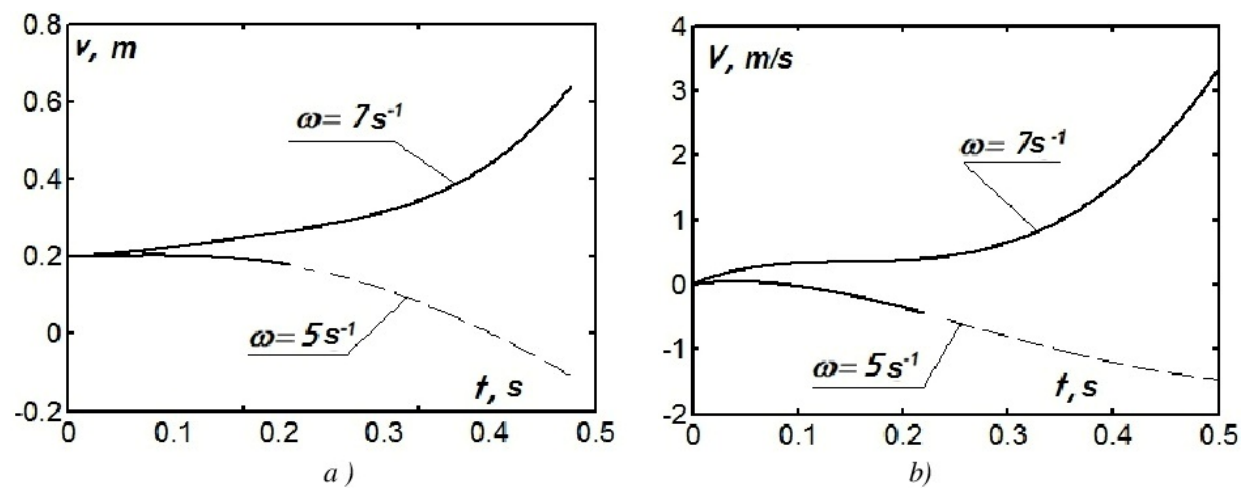

Figure 3. Graphs of distance $\nu=\nu(t)-$ a) and relative velocity $V=V(t)-\mathrm{b})$ at $\beta=0$

However, without reaching a rotation axis, after $0,22 s$ plane reaction force is equal to zero, that is to say, a particle does not presses the surface (from this moment on the graphs of distance and velocity are represented using a dashed line). At $\omega=7 s^{-1}$ a particle moves away from a rotation axis and after $0,5 s$ it is more than $0,6 \mathrm{~m}$ away from it and it gains velocity of more than $3 \mathrm{~m} / \mathrm{s}$. Plane reaction force increases as well.

The equation (17) enables finding the parameters of particle motion in radial direction only. However, initial velocity of a particle entering a plane may have another direction, for example, the one that is parallel to a rotation axis as is the case in snow throwing machines for delivering snow on a rotor blade. In this case it is necessary to solve the system (14) using numerical methods at $u \neq$ const or the system (13) at $\beta=0$. Figure 4 shows graphical representations of particle motion at $\beta=0$, which enters a plane with various initial velocities along $u$ axis and zero initial velocity in radial direction $\left(v^{\prime}=0\right)$.

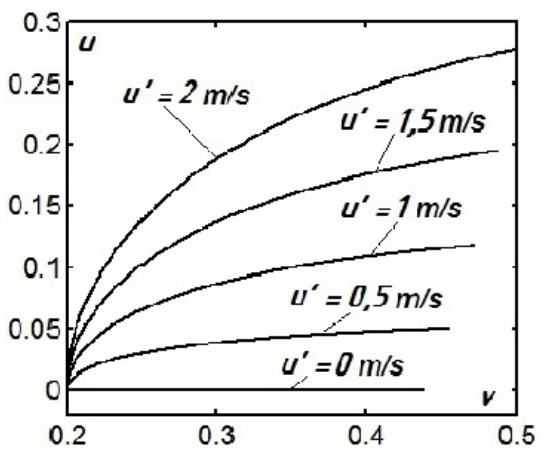

a)

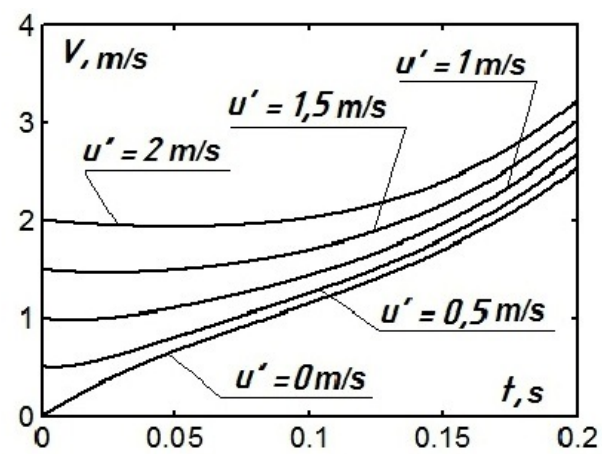

b)

a) trajectories of particle sliding; b) graphs of velocities

Figure 4. Graphical representations of particle motion $\left(\beta=0, \omega=10 s^{-1}, f=0,3, \nu_{0}=0,2 \mathrm{~m}\right)$

In addition, the system of differential equations (13) makes it possible to find trajectories of particle sliding at $\omega=0$, that is to say, when a plane is fixed. For example, let us take an inclination angle $\beta$ of a plane which is equal to a friction angle. For $f=0,3$ this angle has the following value: $\beta=\operatorname{arctg} f=16,70$. Figure 5 , a shows trajectories of particle motion at various angular velocities including $\omega=0$ that have been built using numerical methods. At the beginning of its motion a particle was given initial velocity $V=4 \mathrm{~m} / \mathrm{s}$ along $Y \equiv v$ axis. It traces out a curvilinear trajectory and after a certain time $(3 \mathrm{~s})$ it enters a rectilinear trajectory, which coincides 
with the line of the greatest inclination of a plane. Here, its velocity is stabilized and it becomes twice less than the initial one (Fig. 5, b).

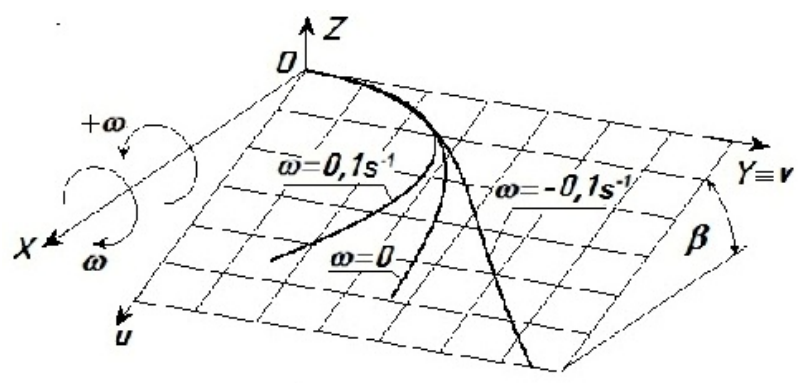

a)

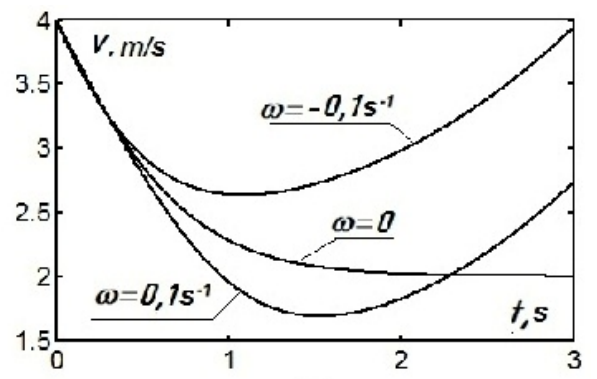

b)

a) trajectories of sliding over a plane; b) graphs of change in velocity over time

Figure 5. Graphical representations of particle motion over a plane, which has an inclination angle $\beta$ equal to a friction angle

Then a particle moves along the line of the greatest inclination with a stabilized velocity. Such a result is in a complete agreement with the result obtained in paper [18], which considers particle motion over an inclined plane at its side feed.

If a plane is given a rotating motion with low angular velocity under previous initial conditions, motion trajectories and graphs of velocity change (Fig. 5).

Let us consider a general case when angle $\beta 0$. At $\beta=0$ and at $u=$ const (that is to say, without relative initial velocity along a rotation axis) a particle moves in radial direction (Fig. 4 , a at $u^{\prime}=0$ ). Let us find out how a particle moves, if angle $\beta$ is gradually increased. Figure 6 shows trajectories of particle sliding at various values of angle $\beta$. Figure 6 , a represents trajectories that a particle traces in $0,5 \mathrm{~s}$. At $\beta=0$ it moves in radial direction. If angle $\beta$ increases, a particle trajectory begins to deviate from radial direction but it moves practically rectilinearly. The length of the distance covered gradually decreases. A dashed line is used to represent a trajectory in case when angle $\beta$ is equal to a friction angle $\beta=\operatorname{arctg} f$. Figure 6 , b shows relative particle motion at further increase of angle $\beta$ over the time of $1,5 \mathrm{~s}$. The figure shows that even an insignificant increase in angle $\beta$ results in a sharp decrease in the distance covered. Here, the angle of deviation from radial direction increases and the trajectory remains rectilinear. At further increase of angle $\beta$, the trajectory of a particle becomes curvilinear and there is a moment when reaction of a plane becomes equal to zero, that is to say, there is detachment of a particle from a plane. Figure 6 , c shows trajectories of relative particle motion during $0,5 \mathrm{~s}$, here, a heavy line represents the trajectory where particles press a plane. At angle $\beta=45^{0}$ the detachment of a particle from a plane happens in $0,4 \mathrm{~s}$ and at $\beta=60^{0}-$ in $0,175 \mathrm{~s}$. Thus, if angle $\beta$ is close to $90^{\circ}$, relative particle motion over a plane becomes impossible. At $\beta=90^{\circ}$ it is impossible from a logical point of view, since a plane is vertical and there is no interaction with a particle.
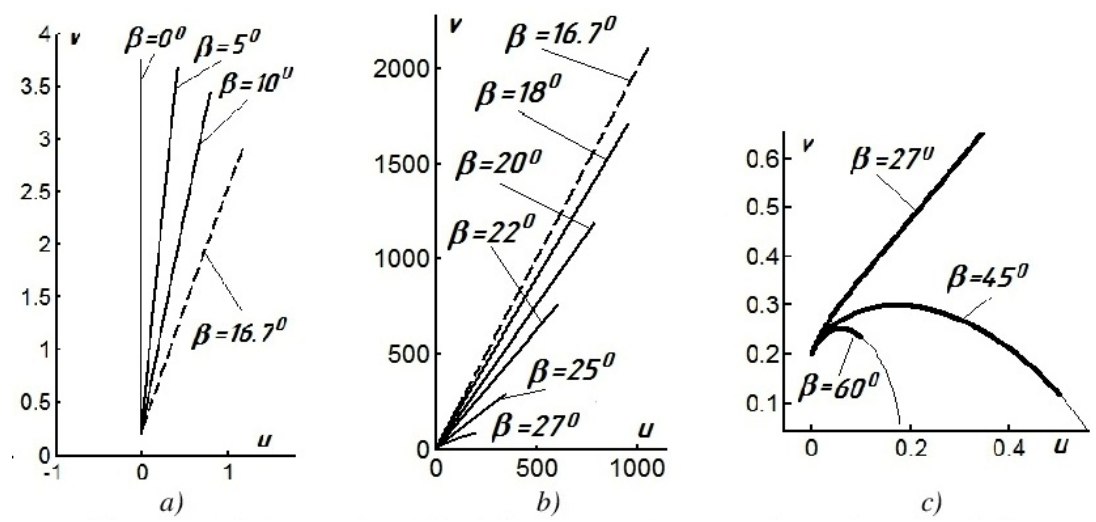

a) $\left.\left.-\omega=10 s^{-1} ; \quad b\right)-f=0,3 ; \quad c\right)-\nu_{0}=0,2 m$

Figure 6 . Trajectories of particle sliding over a plane at various values of angle $\beta$ 
Thus, under our initial conditions and at angular velocity $\omega=10^{s-1}$, transition from rectilinear to curvilinear trajectory of relative motion occurs, if angle $\beta$ is close to $27^{0}$. We have considered this transition in details during $5 \mathrm{~s}$ after the beginning of motion, when a particle covers a great distance. Figure 7 , a represents trajectories of relative motion, which show that a change in angle $\beta$ from 260 to 270 , that is to say, within the range of one degree, results in the change of a trajectory from rectilinear to curvilinear. If a trajectory is rectilinear, particle pressure on a plane increases and if a trajectory is curvilinear, it becomes equal to zero over a certain time. Figure 7 , b shows graphs of pressure change for a particle weighting $0,01 \mathrm{~kg}$. For a particle that moves along a curvilinear trajectory (at $\beta=26,8^{0}$ ), pressure becomes equal to zero in $4,86 \mathrm{~s}$. At great values of angle $\beta$ the detachment of a particle happens almost immediately after its entering a plane as it has been previously shown.

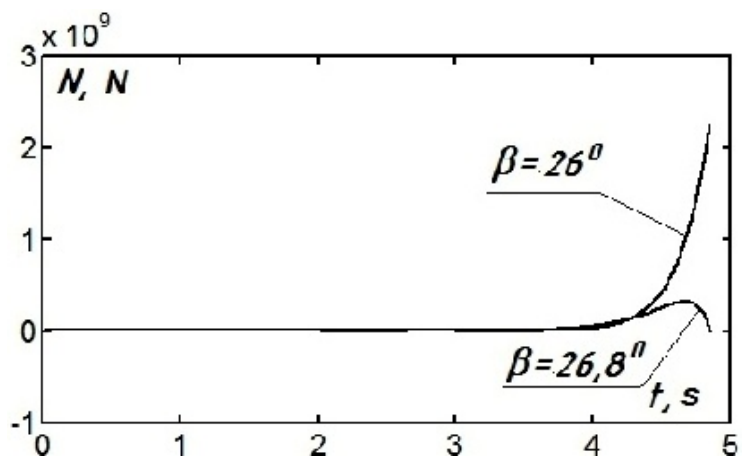

a) motion trajectories; b) graph of pressure change

Figure 7. Graphical representations of particle motion during $5 \mathrm{~s}$ at $\omega=10 \mathrm{~s}^{-1}, f=0,3, \nu_{0}=0,2 \mathrm{~m}$

If there is curvilinear motion, a particle turns in the direction of $u$ axis (Fig. 6, c). If a plane is positioned as it is shown in Figure 1, b, this direction coincides with the direction of the line of the greatest inclination of a plane. We can assume that such a change in the direction of a trajectory is the result of the action of weight force of a particle. However, calculations with dropping particle weight $($ at $g=0)$ show that trajectories and graphs of velocity change differ with and without weight (Fig. 8). It can be explained by the fact that the main force, which causes particle deviation from a rectilinear trajectory, is the component of Coriolis force.

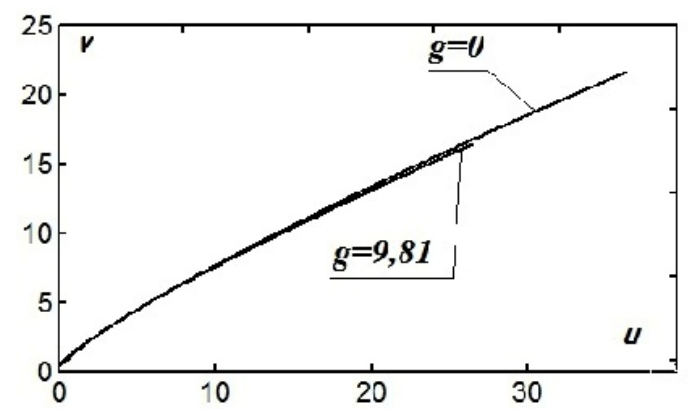

a)

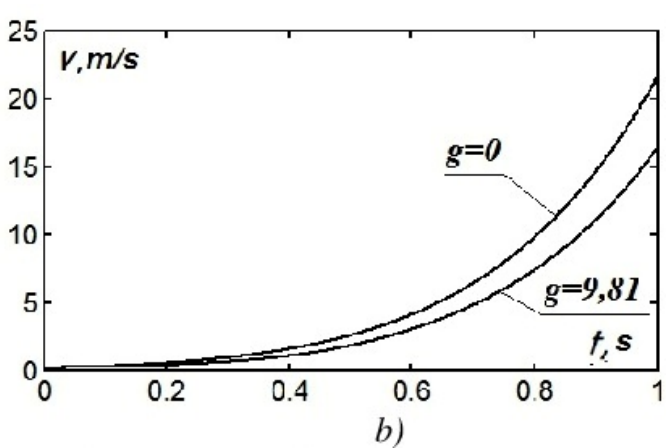

b)

a) motion trajectories; b) a graph of relative velocity change

Figure 8. Graphical representations of particle motion during $1 \mathrm{~s}$ at $\beta=27^{0}, \omega=10 \mathrm{~s}^{-1}, f=0,3, \nu_{0}=0,2 s$ :

If angle $\beta=0$, Coriolis force is directed perpendicular to a plane and does not shift a particle from a rectilinear trajectory. A particle moves in radial direction under the action of centrifugal force. At $\beta \neq 0$ there is a component of Coriolis force that, at first, causes deviation of rectilinear motion from radial direction and then, if angle $\beta$ increases, there is trajectory bending towards $u$ axis.

If weight is ignored, a particle picks up speed faster and covers a greater distance. Obviously, it is due to the fact that friction force decreases in those moments of rotational motion of a plane when a particle is located under it. 


\section{Conclusions}

When a particle enters an inclined plane, which rotates about a horizontal axis with constant angular velocity, a particle traces out a relative trajectory on a plane (a sliding trace), which form depends on the angle $\beta$ between a plane and a rotation axis. If angle $\beta=0^{0}$, a relative trajectory is a straight line along which a particle picks up speed in radial direction. At side material feed, that is to say, if a particle enters a plane having certain initial velocity in the direction that is parallel to a rotation axis, a particle traces a curvilinear trajectory on a plane, which approaches rectilinear radial direction over a certain time. If $\beta \neq 0$, the pattern of particle motion changes. At low angle values it moves in rectilinear direction, which makes a certain angle with radial direction. This angle increases, if angle $\beta$ increases, here, the distance of particle sliding over a plane during the same time period decreases rapidly. If there is a further increase of angle $\beta$, there is a moment when the trajectory of particle motion becomes curvilinear; here, there is trajectory bending towards $u$ axis. Here, a particle moves along a curvilinear trajectory only until a certain moment when plane reaction becomes equal to zero and there is particle detachment from a plane. If angle values are close to $90^{\circ}$, particle motion over a plane becomes impossible, since it is detached from a plane almost immediately after entering. If $\beta=90^{\circ}$, motion is impossible due to the fact that a plane is vertical and there is no interaction with a particle.

\section{References}

1 Klendii M.B. Analytical model of arranging soil-tilling concave disks for determination of geometrical and technical data / M.B. Klendii, S.F. Pylypaka // Науковий вісник НУБіП України. Сер. «Техніка та енергетика АПК». - 2016. - № 241. - С. 140-150.

2 Pylypaka S.F. Particle motion over the surface of a rotary vertical axis helicoid / S.F. Pylypaka, M.B. Klendii, O.M. Klendii // INMATEH: Agricultural Engineering. - 2017. - Vol. 51. - No. 1. P. 15-28.

3 Василенко П.М. Теория движения частицы по шероховатым поверхностям сельскохозяйственных машин / П.М. Василенко. - Киев: УАСХН, 1960. - 283 с.

4 Заика П.М. Избранные задачи земледельческой механіки / П.М. Заика. - Киев: УСХА, 1992. $507 \mathrm{c.}$

5 Адамчук В.В. Дослідження руху частинки по плоскому диску, який обертається навколо перпендикулярної осі, нахиленої до горизонту / В.В. Адамчук, В.М. Булгаков, Д.Г. Войтюк, С.Ф. Пилипака // Вісник Львівського національного аграрного університету: агроінженерні дослідження. - 2008. - № 12(2). - C. 189-197.

6 Адамчук В.В. Дослідження відносного руху матеріальної частинки по похилій лопатці відцентрового апарата / В.В. Адамчук, В.М. Булгаков, С.Ф. Пилипака, Я. Франчак // Науковий вісник Луганського національного університету. Сер. Технічні науки. - 2005. - № 29. - С. 32-56.

7 Клендій М.Б. Розробка конструкції та облрунтування параметрів лопатевого транспортеразмішувача / М.Б. Клендій // Науковий вісник Національного аграрного університету. - 2005. Вип. 92. - С. 533-540.

8 Gevko R.B. The investigation of the process of a screw conveyer safety device actuation / R.B. Gevko, O.M. Klendii // INMATEH: Agricultural Engineering. - 2014. - Vol. 42. - No. 1. - P. 55-60.

9 Гевко Р. Поектування пневмо-механічного транспортера сипких матеріалів / Р. Гевко, В. Дзюра, Р. Романовський // Вісник Тернопільського національного технічного університету. - 2009. - Т. 14. - № 4. - C. 84-88.

10 Hevko R.B. Mathematical model of the pneumatic-screw conveyor screw mechanism operation / R.B. Hevko, V.O. Dzyura, R.M. Romanovsky // INMATEH: Agricultural Engineering. - 2014. Vol. 44. - No. 3. - P. 103-110.

11 Hevko R.B. Investigation of a transfer branch of a flexible screw conveyer / R.B. Hevko, M.B. Klendii, O.M. Klendii // INMATEH: Agricultural Engineering. - 2016. - Vol. 48. - No. 1. - P. 29-34.

12 Hevko R.B. Development of design and investigation of operation processes of loading pipes of screw conveyors / R.B. Hevko, R.I. Rozum, O.M. Klendii // INMATEH: Agricultural Engineering. - 2016. Vol. 50. - No. 3. - P. 89-96. 
13 Hevko R.B. Feasibility study of the process of transpotration and stirring of mixture in continuous-flow conveyers / R.B. Hevko, B.O. Yazlyuk, M.V. Liubin, O.A. Tokarchuk, O.M. Klendii, V.R. Pankiv // INMATEH: Agricultural Engineering. - 2017. - Vol. 51. - No. 1. - P. 49-58.

14 Klendii M.B. Inverrelation between incidence ange and roll ange of concave disks of soil tillage implements / M.B. Klendii, O.M. Klendii // INMATEH: Agricultural Engineering. - 2016. — Vol. 49. — No. 2. P. 13-20.

15 Вітровий А.О. Силовий аналіз робочого органу гнучкого гвинтового конвеєра / А.О. Вітровий, Р.Б. Гевко // Сільськогосподарські машини: збірник наукових статей Луцького державного технічного університету. - 1998. - № 4. - С. 8-14.

16 Hevko B.M. Improvement of machine safety devices / B.M. Hevko, R.B. Hevko, O.M. Klendii, M.V. Buriak, Y.V. Dzyadykevych, R.I. Rozum // Acta Polytechnica, Journal of Advanced Engineering. - 2018. - Vol. 58. - No. 1. - P. 17-25.

17 Baranovsky V.M. Justification of rational parameters of a pneumoconveyor screw feeder / V.M. Baranovsky, R.B. Hevko, V.O. Dzyura, O.M. Klendii, M.B. Klendii, R.M. Romanovsky // INMATEH: Agricultural Engineering. - 2018. - Vol. 54. - No. 1. - P. 15-24.

18 Пилипака С.Ф. Траєкторії руху частинок по шорсткій похилій площині при їх боковій подачі / С.Ф. Пилипака, А.В. Несвідомін // Прикладна геометрія та інженерна графіка. - 2011. - № 87. C. $36-41$.

\author{
С.Ф. Пилипака, Н.Б. Клендий, В.И. Троханяк
}

\title{
Көлденең осьті айналатын жазықтықта жататын және онымен белгілі бұрыш жасайтын бөлшектің қозғалысы
}

\begin{abstract}
Көлденең осьті айналатын жазықтықтағы материалдық бөлшектердің салыстырмалы қозғалысының дифференциалдық теңдеулері құрастырылды. Айналу өсіне байланысты жазықтықтың орны мәні нөлден тоқсан градусқа дейінгі аралықтағы бұрышпен берілді. Бұрышы нөлге тең болған кезде жазықтың айналу осі арқылы өтеді, ал тоқсан градус болғанда ол айналу осіне перпендикуляр болады. Теңдеулер сандық әдістермен шешілді. Бұрыштық шеткі позициясы үшін аналитикалық шешім табылды.
\end{abstract}

Kiлm сөздер: топырақ өңдейтін диск, айналмалы қозғалыс, қозғалыстың дифференциалдық теңдеулері.

С.Ф. Пилипака, Н.Б. Клендий, В.И. Троханяк

\section{Движение частицы по плоскости, вращающейся вокруг горизонтальной оси и составляющей с ней определенный угол}

\footnotetext{
Составлены дифференциальные уравнения относительного движения материальной частицы по плоскости, которая вращается вокруг горизонтальной оси. Положение плоскости по отношению к оси вращения задается углом, который может иметь значение из промежутка от нуля до девяноста градусов. При угле, равном нулю, плоскость проходит через ось вращения, при девяноста градусах она перпендикулярна оси вращения. Уравнения решены численными методами. Для крайних положений угла найдено аналитическое решение.
}

Ключевые слова: почвообрабатывающий диск, вращательное движение, дифференциальные уравнения движения. 


\section{References}

1 Klendii, M.B., \& Pylypaka, S.F. (2016). Analytical model of arranging soil-tilling concave disks for determination of geometrical and technical data. Naukovii visnik NUBiP Ukraini: Seriia «Tekhnika ta energetika APK»-Scientific Bulletin of NUBiP of Ukraine. Series. «Technique and power engineering agroindustrial complex», Vol. 241, 140-150.

2 Pylypaka, S.F., Klendii, M.B., \& Klendii, O.M. (2017). Particle motion over the surface of a rotary vertical axis helicoids. INMATEH: Agricultural engineering, Vol. 51, 1, 15-28.

3 Vasilenko, P.M. (1960). Teoriia dvizheniia chastitsy po sherokhovatym poverkhnostiam selskokhoziaistvennykh mashin [Theory of particle motion over rough surfaces of agricultural machinery]. Kiev: UASKhN [in Russian].

4 Zaika, P.M. (1992). Izbrannye zadachi zemledelcheskoi mekhaniki [Selected tasks of agricultural mechanics]. Kiev: USKhA [in Russian].

5 Adamchuk, V.V., Bulhakov, V.M., Voitiuk, D.H., \& Pylypaka, S.F. (2008). Doslidzhennia rukhu chastinki po ploskomu disku, iakii oberta€tsia navkolo perpendikuliarnoi osi, nakhilenoi do horizontu [Investigation of particle motion over a flat disk, which rotates about a perpendicular axis that is inclined to a horizon]. Visnik Lvivskoho natsionalnoho ahrarnoho universitetu: ahroinzhenerni doslidzhennia - Bulletin of Lviv National Agrarian University: agricultural engineering research, Vol. 12, 2, 189-197 [in Ukrainian].

6 Adamchuk, V.V., Bulhakov, V.M., Pylypaka, S.F., \& Franchak, Yan. (2005). Doslidzhennia vidnosnoho rukhu materialnoi chastinki po pokhilii lopattsi vidtsentrovoho aparata [Investigation of relative material particle motion over an inclined blade of a centrifugal machine]. Naukovii visnik Luhanskoho natsionalnoho universitetu. Seriia Tekhnichni nauki - Scientific Bulletin of Luhansk National University. Series Technical Sciences, LNAU, Vol. 29, 32-56 [in Ukrainian].

7 Klendii, M.B. (2005). Rozrobka konstruktsii ta obhruntuvannia parametriv lopatevoho transporterazmishuvacha [Design development and substantiation of the parameters of a bladed conveyer-mixer]. Naukovii visnik Natsionalnoho ahrarnoho universitetu - Scientific Bulletin of National Agrarian University, Vol. 92, 2, 533-540 [in Ukrainian].

8 Gevko, R.B., \& Klendii, O.M. (2014). The investigation of the process of a screw conveyer safety device actuation. INMATEH: Agricultural Engineering, Vol. 42, 1, 55-60.

9 Hevko, R., Dzyura, V., \& Romanovsky, R. (2009). Poektuvannia pnevmo-mekhanichnoho transportera sipkikh materialiv [Designing of pneumo-mechanical conveyer for loose materials]. Visnik Ternopilskoho natsionalnoho tekhnichnoho universitetu - Bulletin of I.Pyliui Ternopil State Technical University, Vol. 14, 4, 84-88 [in Ukrainian].

10 Hevko, R.B., Dzyura, V.O., \& Romanovsky, R.M. (2014). Mathematical model of the pneumatic-screw conveyor screw mechanism operation. INMATEH: Agricultural engineering, Vol. 44, 3, 103-110.

11 Hevko, R.B., Klendii, M.B., \& Klendii, O.M. (2016). Investigation of a transfer branch of a flexible screw conveyer. INMATEH: Agricultural engineering, Vol. 48, 1, 29-34.

12 Hevko, R.B., Rozum, R.I., \& Klendii, O.M. (2016). Development of design and investigation of operation processes of loading pipes of screw conveyors. INMATEH: Agricultural engineering, Vol. 50, 3, 89-96.

13 Hevko, R.B., Yazlyuk, B.O., Liubin, M.V., Tokarchuk, O.A., Klendii, O.M., \& Pankiv, V.R. (2017). Feasibility study of the process of transpotration and stirring of mixture in continuous-flow conveyers. INMATEH: Agricultural engineering, Vol. 51, 1, 49-58.

14 Klendii, M.B., \& Klendii, O.M. (2016). Inverrelation between incidence ange and roll ange of concave disks of soil tillage implements. INMATEH: Agricultural Engineering, Vol. 49, 2, 13-20.

15 Vitrovyi, A.O., \& Hevko, R.B. (1998). Silovii analiz robochoho orhanu hnuchkoho hvintovoho konveera [Power analysis of the operating element of a flexible screw conveyer]. Agricultural machinery: zbirnik naukovikh statei Lutskoho derzhavnoho tekhnichnoho universitetu - Agricultural Machinery. Collection of Scientific Papers, Vol. 4, 8-14 [in Ukrainian].

16 Hevko, B.M., Hevko, R.B., Klendii, O.M., Buriak, M.V., Dzyadykevych, Y.V., \& Rozum, R.I. (2018). Improvement of machine safety devices. Acta Polytechnica, Journal of Advanced Engineering, Vol. 58, 1, $17-25$. 
17 Baranovsky, V.M., Hevko, R.B., Dzyura, V.O., Klendii, O.M., Klendii, M.B., \& Romanovsky, R.M. (2018). Justification of rational parameters of a pneumoconveyor screw feeder. INMATEH: Agricultural engineering, Vol. 54, 1, 15-24.

18 Pylypaka, S.F., \& Nesvidomin, A.V. (2011). Traektoriy rukhu chastinok po shorstkii pokhilii ploshchini pri ikh bokovii podachi [Trajectories of particle motion over rough inclined planes at side feed]. Prikladna heometriia ta inzhenerna hrafika - Applied Geometry and Engineering Graphics, Vol. 87, 36-41, [in Ukrainian]. 